\title{
Hubungan Antara Kecerdasan Emosional Dan Kesiapan Belajar Dengan Hasil Belajar Biologi Kelas XI SMA Negeri 8 Bulukumba
}

\author{
Sitti Asma \\ Universitas Muhammadiyah Bone \\ Email: asmahrappocini@gmail.com
}

\begin{abstract}
Abstrak
Penelitian ini bertujuan untuk : (i) Mengetahui hubungan kecerdasan emosional dengan hasil belajar biologi, (ii) Mengetahui hubungan kesiapan belajar dengan hasil belajar biologi, (iii) mengetahui hubungan kecerdasan emosional dan kesiapan belajar secara bersama-sama terhadap hasil belajar biologi siswa kelas XI SMA Negeri 8 Bulukumba. Penelitian ini merupakan penelitian Ex post facto. Populasi dalam penelitian ini adalah kelas XI IPA sebanyak 140 siswa. Teknik pengambilan sampel Proportional Random Sampling dengan besaran sampel 100 siswa. Teknik Pengumpulan data melalui angket dan dokumentasi. Analisis data menggunakan uji korelasi dan uji regresi. Hasil penelitian menunjukkan bahwa: (i) terdapat hubungan yang signifikan antara kecerdasan emosional dengan hasil belajar biologi. Koefisien korelasi sebesar 0,586 dan nilai signifikan sebesar 0,339, (ii) Terdapat hubungan yng signifikan antara kesiapan belajar dengan hasil belajar biologi. Koefisien korelasi sebesar 0,463 dan nilai siginifikansi sebesar 0,215, dan (iii) terdapat hubungan yang signifikan antara kecerdasa emosional dan kesiapan belajar secara bersama-sama terhadap hasil belajar biologi. Koefisien korelasi sebesar 0,641 dan nilai signifikansi sebesar 0,354.
\end{abstract}

Kata Kunci: Kecerdasan Emosional, Kesiapam Belajar, Hasil Belajar

\section{PENDAHULUAN}

Pendidikan merupan salah satu aspek pembangunan dan sekaligus merupakan syarat mutlak untuk mewujudkan pembangunan nasional, Pendidikan bersifat dinamis, melalui pendidikan kita dapat mempertahankan atau mengembangkan nilai-nilai yang kita kehendaki sesuai dengan usaha-usaha pengembangan manusia seutuhnya. Pernyataan tersebut sejan dengan fungsi dan tujuan pendidikan nasional yaitu: mengembangkan kemampuan dan membentuk watak serta peradaban bangsa yang bermartabat dalam rangka mencerdaskan kehidupan bangsa bertujuajn untuk mengembangkan potensi agar menjadi manusia yang beriman dan bertaqwa kepada tuhan yang Maha Esa, berakhlak mulia, sehat jasmani dan rohani, berilmu cakap, kreatif, mandiri dan menjadi warga Negara yang demokratis serta bertanggung jawab (undang-undang Republik Indonesia No. 20 tahun 2003 tentang system pendidikan nasional).
Hasil belajar merupakan indicator kualitas dan kuantitas pengetahuan yang telah dikuasai oleh siswa. Tinggi rendahnya hasil belajar dapa menjadi indicator sedikit banyaknya pengetahuan yang dikuasai sesorang dalam bidang studi yang dipilihnya, Banyak factor yang mempengaruhi hasil belajar, antara lain factor external yang mencakup aspek lingkungan fisik seperti lingkunagn sekolah, kondisi sarana dan prasarana beajar, materi pelajaran dan proses belajar mengajar, sedangkan factor internal mencakup aspek fisik seperti pancaindra serta aspek psikologi seperti disiplin, bakat, minat intekegnsi, serta kecerdasan emosional dan motivasi berprestasi. Berdasarkan kenyataan dilapangan menunjukkan, seseorang siswa mempunyai IQ ini tidak menjamin keberhasilan dalam pembelajaran, namun seorang siswa yang ber IQ sedang tetapi IQ nya tinggi lebih besar peluang keberhasilannya dalam kegiatan pembelajaran. Hal ini seperti ditegaskan oleh 
Goleman (2003: 21) bahwa kecerdasan (IQ) dan kecerdasan emosi (EQ) merupakan factor yang mempengaruhi kinerja seseorang, namun kecerdasan emosilah yang lebih berperan untuk menghasilkan kinerja yang cemerlang”. Sejalan dengan penelitian yang dilakukan Yani (2012) bahwa kecerdasan emosional mempuanyai hubungan positif dan signifikan dengan prestasi belajar.

Kesiapan belajar tidak hanya diartikan dalam kesiapan fisik dan psikis saja, tetapi juga diartikan siap dalam materi. Kesiapan metri merupakan alat yang mendukung pembelajaran seperti adanya bahan yang dipelajari berupa buku, catatn pelajaran, modul untuk pembelajaran (Djamarah, 2002: 35) Kesiapan siswa dalam belajar merupakan kondisi diri siswa yang telah dipersiapkan untuk suatu kegiatan belajar. Sehingga kesiapan belajar merupakan kebutuhan yang disadari mendorong usaha untuk mencapai tujuan belajar. Hal tersebut dinyatakan oleh Long dan Agyekum, bahwa terdapat beberapa hal yang dalam kesiapan belajar khususnya aspek mental dan emosional meliputi kecerdasan, kemandirian, kepercayaan diri, kegigihan, inisiatif, kreatifitas, kemampuan untuk kritis mengevaluasi diri sendiri, keinginan untuk belajar dan orientasi tugas yang berpengaruh terhadap hasil belajar siswa, Hasil penelitian Darso (2011) melaporkan terdapat hubungan positif dan signifikan antara kesiapan belajar dengan hasil belajar.Berdasarkan uraian dilator belakang, maka peneliti ingin meneliti mengenai hubungan factor-faktor yang berpengaruh terhadap hasil belajar terutapafaktor internal yaitu kecerdasan emosional dan kesiapan belajar, dimana kedua factor internal tersebut menunjang pencapaian hasil belajar siswa.

\section{TINJAUAN PUSTAKA}

\section{A. Hasil Belajar}

1. Pengertian Hasil Belajar

Menurut Rifai (2009: 85) hasil belajar merupakan perubahan perilaku yang diperoleh peserta didik setelah mengalami kegiatan belajar. Perolehan aspek-aspek perubahan perilaku tersebut tergantung pada yang dipelajari oleh siswa atau peserta didik, sedangkan menurut handayani dan Sapir (2009: 12) hasil belajar terdiri dari tiga aspek, yaitu kognitif, afektif dan psikomotor. Hasil belajar kognitif merupakan tingkat pemahaman siswa terhadap materi.

Hasil belajar menurut Gagne dan Driscoll (dalam Sopah, 2000: 126) adalah kemampuankemampuan yang dimiliki siswa sebagai akibat perbuatan belajar dan yang dapat diamati melalui penampilan siswa (Learner's Performance).

Hasil belajar di sekolah dapat dilihat dari penugasan siswa pada mata pelajaran yang ditempunya. Tingkat penugasan pelajaran atau hasil belajar dalam mata pelajaran tersebut di sekolah dilambangkan dengan angka-angka atau huruf, seperti angka 0-10 pada pendidikan dasar dan menengah dan huruf A, B, C, D pada pendidikan tinggi (Sukmadinata, 2003: 86).

Secara garis besar, teknik evaluasi yang digunakan dapat digolongkan menjadi 2 macam, yaitu tekhnik tes terdiri atas tulis dan lisan. Tekhnik non tes terdiri atas skala bertingkat, koesioner, daftar cocok, wawancara, pengamatan, riwayat hidup. Proses Belajar mengajar, penilaian dilakukan dengan mengukur seberapa jauh tujuan-tujuan instructional telah dicapai siswa (Arikumto: 2006: 89)

Menurut Anderson \& Krathwohl (2010: 97), ada tiga macam hasil belajar, yaitu 1) Aktifitas belajar, 2) belajar manghafal, dan 3) belajar yang bermakna. Berdasarkan uraian di atas makan dapat disimpulkan bahwa hasil belajar adalah pola perbuatan, tindakan nilai, sikap, apresiasi dan keterampilan yang didapatkan oleh para siswa atau peserta didik melalui proses belajar yang mencakup kemampuan kognitif, afektif dan juga psikomotorik. Berkaitan dengan belajar biologi maka hasil belajar biologi merupakan suatu hasil yang diperoleh siswa dalam menekuni dan mempelajari Biologi. 
2. Faktor - Faktor yang Mempengaruhi Hasil Belajar

Menurut Rifai dan Chatarine (2009: 97) menyatakan bahwa factor-faktor yang memberikan kontribusi terhadap proses dan hasil belajar adalah kondisi internal dan eksternal peserta didik. Sedangkan Slameto (2010: 54) menerangkan bahwa factor-faktor yang mempengaruhu hasil belajar adalah:

a. Faktor Internah meliputi:

1) Faktor Jsmaniah terdiri dari factor kesehatan dan factor cacat tubuh.

2) Faktor psikologis terdiri dari intelegensi, perhatian, minat, bakat, motif, kematangan dan kesiapan

3) Faktor Kelelahan baik kelelahan secara jasmani maupun kelelahan secara rohani.

b. Faktor Eksternal meliputi:

1) Faktor keluarga terdiri dari cara orang tua mendidik, relasi antar anggota keluarga, suasana rumah, keadaan ekonomi keluarga pengertian orang tua dan latar belakang kebudayaan.

2) Faktor sekolah terdiri dari metode mengajar, kurikulum, relasi guru dengan siswa, relasi siswa dengan siswa, disiplin sekolah, alat pelajaran, waktu sekolah, standart pelajaran di atas ukuran, keadaan gedung, metode belajar dan tugas rumah

3) Faktor masyarakat terdiri dari kegiatan siswa dalam masyarakat, teman bergaul dan bentuk kehidupan masyarakat.

Berdasarkan dari beberapa pendapat para ahli mengenai factor-faktor di atas maka dapat disimpulkan bahwa hasil belajar biologi dapat disimpulkan bahwa hasil belajar biologi dapat dipengaruhi oleh dua factor utama yaitu factor internal dan juga factor eksternal, yang mana factor internal merupakan factor-faktor yang bersumber dari individu masing-masing siswa, sedangkan factor eksternal yaitu factor-faktor yang bersumber dari luar individu siswa itu sendiri

\section{B. Kecerdasan Emosional}

1. Pengertian Kecerdasan Emosional
Kata Emosi berasal dari bahasa latin yaitu Movere yang berarti menggerakkan atau bergerak. Sedangkan emosi menurut kamus bahasa inggris Oxford adalah setiap kegiatan atau pergolakan pikiran, perasaan, nafsu atau setiap keadaan mental yang hebat atau meluaoluap, emosi merujuk kepada sesuatu perasaan dan pikiran-pikiran khasnya, suatu keadaan biologis dan psikologis serta serangkaian kecenderungan untuk bertindak. Emosi dapat dikelompokkan sebagai suatu rasa amarah, sedikit, takut, jengkel, malu dan lain-lain (Goleman, 2004: 411)

Menurut Cooper dan Sawat (Agus Efend, 2006: 172) bahwa kecerdasan emosional adalah kemampuan merasakan, memahami dan secara efektif menerapkan daya dan kepekaan emosi sebagai sumber energy, informasi, koneksi dan pengaruh-pengaruh yang manusiawi. Sejalan dengan dikemukakan oleh Salovey dan Mayer (dalam Goleman, 2005: 513) berpebdapat bahwa kecerdasan emosional adalah kemampuan memantau dan mengendalikan perasaan diri dan orang lain serta menggunakan perasaan-perasaan untuk memandu pikiran dan tindakan. Berdasarkan berbagi pengertian keceerdasan emosional dapat disimpulkan bahwa kecerdasan emosional merupakan kemampuan mengindera, memahami dan efektif menerapkan kekuatan emosi sebagai sumber energy dan informasi yang apabila mampu dipahami dan dilaksanakan, kecerdasan emosional akan menyediakan kemampuan yang lebih kompleks tentang diri sendiri dan orang lain disekitar kita.

2. Aspek-Aspek Kecerdasan Emosional

Berikut ini adalah uraian kelima dimensi kecerdasan emosi, termasuk kecakapankecakapan yang ada pada masing-masing dimensi tersebut.

a. Kesadaran diri adalah kemampuan individu untuk mengetahui apa yang dirasakan pada suatu saat dan menggunakannya untuk memandu pengambilan keputusan dirisendiri. Memiliki tolak ukur yang realistis atas kemampuan diri dan kepercayaan diri yang kuat (Goleman, 2005: 83). 
b. Pengaturan diri adalah mengelola kondisi, impuls dan sumber daya diri sendiri. Kecakapan emosi yang terkait dengan dimensi ini meliputi; pengendalian diri, dapat dipercaya, hati-hati, adaptabilitas dan inovatif (Goleman, 2004: 130)

c. Motivasi diri adalah dorongan kecenderungan emosi yang mengantar atau memudahkan untuk mencapai tujuan. Kecakapan emosi yang terkait dengan dimensi ini meliputi; dorongan berprestasi, komitmen, inisiatfi dan optimism

d. Empati adalah kesadaran terhadap perasaan, kebutuhan dan kepentingan orang lain, kecakapan emosi yang terkait dengan dimensi ini meliputi : memahami orang lain, orientasi melayani, mengembangkan orang lain, mendayagunakan keragaman dan kesadaran politik

e. Keterampilan social adalah kepintaran dala menggugah tanggapan yang dikehendaki pada orang lain atau merupakan seni dalam menangani emosi orang lain

\section{Kesiapan Belajar}

1. Pengertian Kesiapan Belajar

$$
\text { Menurut Slameto (2003: }
$$

mengemukakan kesiapan adalah keseluruhan kondisi seseorang adalah keseluruhan kondisi seseorang yang membuatnya siap untuk memberi respon atau jawaban di dalam tertentu terhadap suatu situasi. Penyesuaian kondisi pada suatu saat akan berpengaruh atau kecenderungan untuk memberi respon.

Menurut Thorndike (dalam slameto, 2003: 114) kesiapan adalah prasyarat untuk belajar berikutnya. Menurut Hamalik (2003: 41) kesiapan adalah keadaan kapasitas yang ada pada diri siswa dalam hubungan dengan tujuan pengajaran tertentu.

Kesiapan sebagai atau kesediaan seseorang untuk berbuat sesuatu. Sejalan dengan seseorang ahli bernama Cronbach memberikan pengertian tentang kesiapan sebagai segenap sifat atau kekuatan yang membuat seseorang dapat bereaksi yang membuat seseorang dapat bereaksi dengan cara tertentu (Soemanto, 2006: 191).sedangkan menurut Djmarah (2002:35) kesiapan untuk belajar merupakan kondisi diri yang telah dipersiapkan untuk melakukan suatu kegiatan. Menurut Darsono (2000:27) factor kesiapan baik fisik maupun psikologi, merupakan kondisi awal suatu kegiatan belajar.

2. Faktor-Faktor Kesiapan Belajar

Beberapa factor yang dapat mempengaruhi kesiapan belajar siswa yaitu :

a. Menurut darsono (2000: 27) factor kesiapan meliputi kondisi fisik yang tidak kondusif, kondisi psikologi yang kurang baik

b. Menurut Slameto (2003: 113) kondisi kesiapan mencakup 3 aspek, yaitu : (1) Kondisi Fisik, mental dan emosional (2) Kebutuhan - Kebutuhan, Motif dan tujuan (3) Keterampilan pengetahuan dan engertian yang lain yang telah dipelajari

c. Faktor yang membentuk kesiapan meliputi: Perlengkapan dan Pertumbuhan fisik motivasi

\section{METODE PENELITIAN}

\section{A. Jenis Penelitian}

Penelitian ini adalah penelitian "Ex-post Facto" Karena factor yang dikumpulkan sudah ada sebelumnya pada diri responden atau gejala yang timbul tanpa adanya perlakuan dan bersifat "korelasional" artinya jenis penelitian yang menggambarkan apa ada hubungan antar variable.

\section{B. Populasi dan Sample}

Populasi dalam penelitian ini adalah siswa kelas XI IPA SMA Negeri 8 Bulukumba pada tahun pelajaran 2019/2020 dengan jumlah 140 oarang. Teknik Pengambilan sampel adalah Proportional Random Sampling. Karena memberikan peluang yang sama bagi setiap anggota populasi untuk dipilih menjadi sampel dengan jumlah sampel 100 orang.

\section{Variable Penelitian}

Terdapat dua variable dalam penelitian ini, yaitu variable bebas dan variable terikat. Adapun yang menjadi variable bebas dalam penelitian ini adalah kecerdasan emosional dengan symbol $\mathrm{X}_{1}$ kesiapan belajar dengan 
symbol $\mathrm{X}_{2}$ dan variable terikatnya yaitu hasil belajar biologi dengan symbol Y.

\section{Analisis Data}

Data yang diperoleh dari sample penelitian berupa data kuantitatif

\section{Analisis Statistik Deskriptif}

Deskripsi terhadap data mentah yang diperoleh perlu dilakukan untuk memudahkan pemahamamn dan mengetahui tingkat masing-masing variable. Analisis deskriptif digunakan untuk mendiskripsikan atau memberi gambaran terhadap objek yang diteliti melalui data sampel atau populasi sebagaimana adanya, tanpa melakukan analisis dan membuat kesimpulan yang berlaku untuk umum (Sugiyono, 2007: 29).

2. Analisis Inferensial

a. Uji Peryaratan Analisis

Uji persaratan yang dilakukan untuk menentukan jenis statistika yang digunakan. Statistika parametric memerlukan terpenuhinya banyak asumsi. Asumsi yang pertama adalah data harus berdistribusi normal. Selanjutnya Untuk Menguji regresi makan harus terpenuhi asumsi linieritas (Sugiyono, 2007: 210-211)

b. Uji Hipotesis

Untuk menguji hipotesis penelitian dalam penelitian ini diuji dengan uji Statistik parametric, yakni korelasi ganda untuk melihat hubungan antara variable dengan menggunakan tekhnik product moment dari Karl Person

\section{HASIL PENELITIAN \\ PEMBAHASAN}

DAN

\section{Deskripsi Data}

a. Kecerdasan Emosional

Berdasarkan hasil penelitian yang telah dilakukan, data tentang kecerdasan emosional memiliki rentang skor teoretik 132-188. Hasil penelitian menunjukkan bahwa skor tertinggi yang diperoleh responde adalah 188,00 dan skor terendah adalah 132,00. Skor rata-rata sebesar 161,23 median sebesar 161,00 modus sebesar 159,00 dan standartdeviasi sebe Standar deviasi sebesar 11,70.

Tabel 1. Frekuensi dan Persentase Kategori Tingkat Kecerdasan Emosional Siswa Kelas XI IPA di SMA Negeri 8 Bulukumba.

\begin{tabular}{|c|c|c|c|}
\hline Interval Skor & Frekuensi & Persentase $(\%)$ & Kategori \\
\hline $181-215$ & 5 & 5 & Sangat Tinggi \\
$148-180$ & 90 & 90 & Tinggi \\
$114-147$ & 5 & 5 & Sedang \\
$80-113$ & 0 & 0 & Rendah \\
$43-79$ & 0 & 0 & Sangat Rendah \\
\hline
\end{tabular}

Berdasarkan dari table distribusi frekuensi tersebut dapat diketahui bahwa skor kecerdasan emosional berada pada kategori sangat tinggi sebanyak 5 siswa dengan persentase $5 \%$. Sedangkan skor pada kategori tinggi sebanyak 90 siswa dengan persentase $90 \%$ kemudian skor pada kategori sedang sebanyak 5 siswa dengan persentase $5 \%$. Dengan demikian dapat disimpulkan bahwa secara umum tingkat kecerdasan emosional siswa kelas XI IPA di SMA Negeri 8 Bulukumba termasuk pada kategori tinggi.

b. Kesiapan Belajar

Berdasarkan hasil belajar penelitian yang telah dilaksanakan, data tentang kesiapan belajar memiliki rentang skor 108-197. Hasil penelitian menunjukkan bahwa skor tertinggi yang diperoleh responden adalah 197,00 dan skor terendah adalah 108,00. Skor rata-rata sebesar 153,81; median sebesar 153,00 modus sebesar 143,00 dan standar deviasi sebesar 16,42 .

Tabel 2. Frekuensi dan Persentase Kategori Tingkat Kesiapan Belajar Siswa kelas XI IPA di SMA Negeri 8 Bulukumba

\begin{tabular}{|c|c|c|c|}
\hline $\begin{array}{c}\text { Interval } \\
\text { Skor }\end{array}$ & Frekuesnsi & Persentase & Kategori \\
\hline $181-215$ & 6 & 6 & Sangat Tinggi \\
$148-180$ & 56 & 56 & Tinggi \\
$114-147$ & 37 & 37 & Sedang \\
$80-113$ & 1 & 1 & Rendah \\
$43-79$ & 0 & 0 & Sangat rendah \\
\hline
\end{tabular}

Berdasarkan dari table distribusi frekuensi tersebut dapat diketahui bahwa skor kesiapan belajar berada pada kategori sangat tinggi sebanyak 6 siswa dengan persentase $6 \%$. Sebanyak skor tertinggi sebanyak 56 siswa 
dengan persentase 56\% kemudin skor pada kategori sedang sebanyak 37 siswa dengan persentase $37 \%$. Selanjutnya skor terendah sebanyak 1 siswa dengan persentase $1 \%$. Dengan demikian dapat disimpulkan bahwa secara umum kesiapan belajar siswa kelas XI IPA di SMA Negeri 8 Bulukumba termasuk pada kategori tinggi.

c. Hasil Belajar Biologi

Data tentang hasil belajar biologi memiliki rentang teoritik 69-89. Hasil penelitian menunjukkan bahwa skor tertinggi yang diperoleh responden adalah 86,00 dan skor terendah adalah 68,00. Skor rata-rata sebesar 79,25; median sebesar 80.00 modus sebesar 85,00 dan standart deviasi sebesar 5,49.

Tabel 3. Frekuensi dan Persentase Kategori Nilai Hasil Belajar Biologi siswa kelas XI di SMA Negeri 8 Bulukumba berdasarkan pedoman Pengkategorian Hasil Belajar Siswa

\begin{tabular}{|c|c|c|c|}
\hline $\begin{array}{c}\text { Interval } \\
\text { Skor }\end{array}$ & Frekuensi & $\begin{array}{c}\text { Persentase } \\
(\%)\end{array}$ & Kategori \\
\hline $85-100$ & 22 & 22 & Sangat Tinggi \\
$65-84$ & 78 & 78 & Tinggi \\
$55-64$ & 0 & 0 & Sedang \\
$35-54$ & 0 & 0 & Rendah \\
$<34$ & 0 & 0 & Sangat Rendah \\
\hline
\end{tabular}

Berdasarkan table diatas dapat diketahui bahwa skor hasil belajar berada pada kategori sangat tinggi sebanyak 22 siswa dengan persentase $22 \%$ dan kategori tinggi sebanyak 78 siswa dengan persentase $78 \%$ dengan demikian dapat disimpulkan bahwa secara umum hasil belajar biologi siswa kelas XI IPA di SMA Negeri 8 Bulukumba termasuk pada kategori tinggi.

\section{Analisis Inferensial}

a. Uji Normalitas

Uji Normalitas data dalam penelitian ini dilakukan dengan uji Kolmogorov Smirnov. Apabila Nlai sig (2-tailet) > 0,05, maka data dinyatakan berdistribusi normal. Berdasarkan hasil pengolahan data dengan menggunakan uji Kolmogorov smirnov tes diperoleh masing-masing nilai sig (2-tailet) $>0,05$ berarti bahwa data yang diperoleh berdistribusi normal. b. Uji Linieritas

Digunakan untuk menentukan linier atau tidak linier dalam hubungan masing-masing variable. Scatter diagram dan garis best fit digunakan dalam uji linieritas. Berdasarkan data yang ada, variable kecerdasan emosional dengan hasil belajar Biologi siswa memiliki nilai signifikansi linieritas sebesar 0,647. Sedangkan variable kesiapan belajar dengan hasil belajar biologi siswa memiliki nilai signifikansi linieritas sebesar 0,121 . Hal ini berarti bahwa kedua variable tersebut berhubungan linier karena nilai signifikansi lebih besar dari 0,05.

\section{Uji Hipotesis}

a. Hubungan kecerdasan emosional dengan hasil belajar biologi setelah hasil pengukuran kecerdasan emosional dihubungkan dengan hasil belajar siswa biologi diolah dengan menggunakan SPPS 20 for Windows diperoleh hasil analisis regresi sederhana dengan koefisien regresi "b" sebesar 0,289 dan Konstanta "a" sebesar 32,700 sehingga persamaan garis regresi $\quad \mathrm{Y}=32,700+0,289 \mathrm{X}$. untuk mengetahui siginifikansi koefisien regresi dapat dilihat pada table berikut ini:

Tabel 4. Anova Hubungan Kecerdasan Emosional dengan Hasil belajar Biologi SMA Negeri 8 Bulukumba

\begin{tabular}{|c|c|c|c|c|c|}
\hline $\begin{array}{c}\text { Sumber } \\
\text { Variasi }\end{array}$ & $\begin{array}{c}\text { Jumlah } \\
\text { Kuadrat } \\
(\mathrm{JK})\end{array}$ & $\begin{array}{c}\text { Derajat } \\
\text { Bebas }\end{array}$ & $\begin{array}{c}\text { Rerata } \\
\text { Kuadrat } \\
(\mathrm{RK})\end{array}$ & Fhitung & Sig \\
\hline Regresi & 1013,073 & 1 & 1013,073 & 50,198 & 0,000 \\
Kesalahan & 1977,713 & 98 & 20,181 & & \\
Total & 2990,750 & 99 & & \\
\hline
\end{tabular}

Berdasarkan pengujian pada table 4.5 di atas menunjukkan bahwa nilai signifikan 0,000 jauh lebih kecil dari $\alpha 0,01$. Hasil ini berarti bahwa regresi dengan persamaan $\mathrm{Y}=32,700+0,289 \mathrm{X} 1$ signifikan $(\mathrm{p}<0,01)$. Analisis korelasi sederhana terhadap kecerdasan emosional (XI) dan skor hasil belajar biologi (Y) menunjukkan koefisien korelasi ryl sebesar 0,582. Pengujian koefisiean korelasi tersebut menggunakan uji $\mathrm{t}$ yang disajikan pada table 4.6 berikut ini: 
JUPE: Jurnal Pendidikan Mandala

http://ejournal.mandalanursa.org/index.php/JUPE/index
Vol. 6. No. 1 Juni 2021

p-ISSN: 2548-5555 e-ISSN: 2656-6745
Tabel 5. Uji Signifikan Koefisien Korelasi ryl

\begin{tabular}{|c|c|c|c|}
\hline $\begin{array}{c}\text { Cacah Observasi } \\
(\mathrm{df})\end{array}$ & $\begin{array}{c}\text { Koefisien } \\
\text { korelasi }\end{array}$ & Thitung & Ttabel \\
\cline { 3 - 4 } & & $\begin{array}{c}\alpha= \\
0,05\end{array}$ \\
\hline 98 & 0,582 & 7,085 & 1,66 \\
\hline
\end{tabular}

Hasil pengujian pada table 4.6 tersebut menunjukkan bahwa Thitung $=7,085$ lebih besar dan Ttabel 1,66 pada df 98 dengan taraf nyata $\alpha=0,05$. Hal ini berarti bahwa kekuatan hubungan kecerdasan emosional (X1) terhadap hasil belajar biologi (Y) adalah signifikan.

Hasil analisis regresi linier sederhana tersebut memperlihatkan bahwa kecerdasan emosional berhubungan positif terhadap hasil belajar Biologi siswa. Besarnya kontribusi kecerdasan emosional dengan hasil belajar Biologi diketahui dengan membaca koefisien determinasinya $(R)=0,339$. Nilai $R$ tersebut dapat dijelaskan bahwa variasi kecerdasan emosional dengan hasil belajar Biologi sebesar $33,9 \%$ sementara $66,1 \%$ karena factor lainnya seperti lingkungan, kedisiplinan, usia, jenis kelamin dan sebagainya

b. Hubungan kesiapan belajar dengan hasil belajar biologi

Setelah data hasil pengukuran kesiapan belajar dihubungkan dengan hasil belajar biologi diolah dengan menggunakan SPSS 20 for Windows, diperoleh hasil analisis regersi sederhana dengan koefisien regresi "b" sebesar 0,155 dan kontanta "a" sebesar 55,398 sehingga persamaan garis regresi $\mathrm{Y}$ $=55,398+0,155 \mathrm{X} 2$. Untuk mengetahui signifikan koefisien regresi dapat dilihat pada table 4.8 berikut ini:

Tabel 6. Anova hubungn Kesiapan Belajar denga Hasil Belajar Biologi SMA Negeri 8 Bulukumba

\begin{tabular}{|c|c|c|c|c|c|}
\hline $\begin{array}{c}\text { Sumber } \\
\text { Variasi }\end{array}$ & $\begin{array}{c}\text { Jumlah } \\
\text { Kuadrat } \\
(\mathrm{JK})\end{array}$ & $\begin{array}{c}\text { Derajat } \\
\text { Bebas }\end{array}$ & $\begin{array}{c}\text { Rerata } \\
\text { Kuadrat } \\
(\mathrm{RK})\end{array}$ & Fhitung & Sig \\
\hline Regresi & 642,132 & 1 & 642,132 & 26,794 & 0,000 \\
Kesalahan & 2348,618 & 98 & 23,965 & & \\
Total & 2990,750 & 99 & & & \\
\hline
\end{tabular}

Berdasarkan pengujian pada table 4.8 di atas menunjukkan bahwa nilai signifikan 0,000 jauh lebih kecil dari $\alpha 0,01$. Hasil ini berarti bahwa regresi dengan persamaan $\mathrm{Y}=55,398+$
$0,155 \mathrm{X} 2$ signifikan ( $\mathrm{p}$-value $<0,01$ ). Analisis korelasi sederhana terhadap skor kesiapan belajr (X2) dan skor hasil belajar biologi (Y) menunjukkan koefisien korelasi ry2 sebesar 0,463 . Pengujian koefisiesn korelasi tersebut menggunakan uji t yang disajikan pada table 4.9 berikut ini:

Tabel 7. Uji signifikan Koefisien Korelasi ry

\begin{tabular}{|c|c|c|c|}
\hline $\begin{array}{c}\text { Cacah } \\
\text { Observasi } \\
(\mathrm{df})\end{array}$ & $\begin{array}{c}\text { Koefisien } \\
\text { Korelasi }\end{array}$ & Thitung & Ttabel \\
\cline { 3 - 4 } & & $\alpha=0,05$ \\
\hline 98 & 0,463 & 5,176 & 1,66 \\
\hline
\end{tabular}

Hasil pengujian pada table 4.9 tersebut menunjukkan bahwa thitung $=5,176$ lebih besar dan ttabel 1,66 pada df 98 dengan taraf nyata 0,05 . Hal ini berarti bahwa kekuatan hubungan kesiapan belajar (x2) terhadap hasil belajar Biologi (Y) adalah signifian. Hasil Regresi linier sederhana tersebut memperlihatkan bahwa kesiapan belajar berhubungan positif terhadap hasil belajar siswa biologi siswa kelas XI. Besarnya kontribusi kesiapan belajar dengan hasil belajar Biologi diketahui dengan membaca koefisien determinasinya $(\mathrm{R} 2)=0,215$. Nilai $r$ tersebut dapat dijelaskan bahwa variasi kesiapan belajar dengan hasil belajar biologi sebesar 21,5 sementara $78,5 \%$ karena factor lainnya seperti kedisiplinan, usia, jenis kelamin dan sebagainya.

c. Hubungan kecerdasan emosional dan kesiapan belajar secara bersama-sama dengan hasil belajar biologi

Setelah data hasil pengukuran kecerdasan emosional dan kesiapan belajar dalam kaitannya dengan hasil belajar biologi diolah dengan menggunakan SPSS 20 For Windows diperoleh hasil analisis regresi ganda dengan koefisien regresi " $b$ " sebesar 0,239 dan 0,053 dengan konstanta "a" sebesar 32,542, sehingga persamaan garis regresinya adalah $\mathrm{Y}=32,542+$ $0,239 X 1+0,053 X 2$. Untuk mengetahui signifikan koefisien regresi dapat dilihat pada table 4.11 berikut ini 
Tabel 8. Anova hubungan kecerdasan emosional (X1) dan Hasil belajar (X2) dengan hasil belajar biologi (Y)

\begin{tabular}{|c|c|c|c|c|c|}
\hline $\begin{array}{c}\text { Sumber } \\
\text { Variasi }\end{array}$ & $\begin{array}{c}\text { Jumlah } \\
\text { Kuadrat }\end{array}$ & $\begin{array}{c}\text { Deraja } \\
\text { Bebas }\end{array}$ & $\begin{array}{c}\text { Rerat } \\
\text { Kuadrat }\end{array}$ & Fhitung & Sig \\
\hline Regresi & 1058,894 & 2 & 529,447 & 26,584 & 0,000 \\
Kesalahan & 1931,856 & 97 & 19,916 & & \\
Total & 2990,750 & 99 & & & \\
\hline
\end{tabular}

Pengujian pada table 4.11 di atas menunjukkan bahwa nilai signifikan 0,000 jaub lebih kecil dari nilai $\alpha 0,01$. Hasil ini berarti bahwa regresi dengan persamaan $\mathrm{Y}=32,541+$ 0,239X1 + 0,053X2 signifikan $(\mathrm{p}<0,01)$. Analisis korelasi terhadap skor kecerdasan emosional (X1), skor kesiapan belajar (X2) dan skor hasil belajar biologi (Y) menunjukkan koefisien ry1,2 sebesar 0,595

Tabel 9. Uji Signifikan Koefisien Korelasi ry1.2

\begin{tabular}{|c|c|c|c|}
\hline $\begin{array}{c}\text { Cacah } \\
\text { Observasi (df) }\end{array}$ & $\begin{array}{c}\text { Koefisien } \\
\text { Korelasi }\end{array}$ & Thitung & Ttabel \\
\cline { 4 - 4 } & & $\begin{array}{c}\alpha= \\
0,05\end{array}$ \\
\hline 97 & 0,595 & 26,584 & 3,09 \\
\hline
\end{tabular}

Hasil pengujian pada table 4.12 tersebut menunjukkan bahwa $\mathrm{F}$ hitung 26,584 lebih besar dan $\mathrm{F}$ table 3,09 pada df 97 dengan taraf nyata 0,05 . hal ini berarti kekuatan hubungan positif kecerdasan emosional (X1) dan kesiapan belajar (X2) secara bersama-sama dengan hasil belajar Biologi (Y) adalah sangat signifikan. Besarnya kontribusi kecerdasan emosional dan kesiapan belajar secara bersama-sama dengan hasil belajar biologi diketahui dengan membaca koefisien determinasinya (r2) 0,354. Nilai R2 tersesbut dapat dijelaskan bahwa variasi kecerdasan emosional dan kesiapan belajar denga hasil belajar biologi sebesar $35,4 \%$ sementara $64,6 \%$ karena factor lainnya.

\section{KESIMPULAN}

Berdasarkan hasil penelitian dan pembahasan dapat dikemukakan kesimpulan sebagai berikut:

1. Terdapat hubungan signifikan antara kecerdasan emosional dengan hasil belajar Biologi siswa kelas XI IPA di SMA Negeri 8 Bulukumba. Dengan tingkat koefisien (r) sebesar 0,586 (sedang) dan sumbangan efektifnya (R2) sebesar 33,9\%.

2. Terdapat hubungan signifikan antara kesiapan belajar dengan hasil belajar Biologi siswa kelas XI IPA di SMA Negeri 8 Bulukumba. Dengan tingkat koefisien korelasi (r) sebesar 0,463 (sedang) dan sumbangan efektifnya ( $\mathrm{r} 2$ ) sebesar $21,5 \%$

3. Terdapat hubungan signifikan antara kecerdasan emosional dan kesiapan belajar secara bersama-sama dengan hasil belajar biologi dengan tingkat koefisien korelasi (r) sebesar 0,641 (tinggi) dan sumbangan efektifnya (R2) sebesar 35,4\%

A. Berdasarkan hasil penelitian yang diperoleh, maka sarn yang dapat diajukan oleh peneliti adalah sebagai berikut:

1. Dalam upaya peningkatan hasil belajar biologi disemua jenjang pendidikan dan khususnya di jenjang sekolah menengah umum, salah satunya upaya yang dapat dilakukan adalah menumbuhkan dan meningkatkam kecerdasan emosional dan kesiapan belajar yang tinggi dalam diri siswa dengan cara memotivasi siswa sebelum dan sesudah melakukan proses belajar mengajar

2. Bagi para pendidik agar berusaha menumbuhkan dan dalam diri siswa yang diajarnya tentang kecerdasan emosional yang positif, serta memotivasi siswa agar selalu mempersiapkan diri dalam menghadapi setiap mata pelajaran

\section{DAFTAR PUSTAKA}

Anderson, L. W., \& Krathwohl, D. R. 2010. Kerangka Landasan untuk Pembelajaran, Pengajaran dan Asesmen. Yogyakarta: Pustaka Pelajar.

Arikunto, Suharsimi. 2006. Dasar-dasar Evaluasi Pendidikan. Jakarta: Hamalik. Bumi Aksara

Darso. 2011. Kesiapan Belajar Siswa dan Interaksi Belajar Mengajar Terhadap Prestasi Belajar. Jurnal Pendidikan, 
(online), Vol. VII. No. 2 http://jurnal.upi.edu.htm

Darsono, Max. 2000. Belajar dan Pembelajaran. Semarang: IKIP Semarang Press.

Djamarah. 2002. Strategi Belajar Mengajar. Jakarta: Rineka Cipta.

Efendi, Agus. 2005. Revolusi Kecerdasan Abad 21. Bandung: Alfabeta.

Goleman. Daniel. 2003. Emotional Intelegence, Mengapa EQ Lebih Penting Daripada IQ. Jakarta: Gramedia Pustaka Utama

Hamalik, Umar. 2003. Perencanaan Pengajaran Berdasarkan Pendekatan Sistem. Jakarta: PT. Bumi Aksara

Handayani, Sri dan Sapir. 2009. Efektifitas Penerapan Model Pembelajaran Berbasis Masalah dan Pembelajaran Kooperatif Tipe Jigsaw untuk Meningkatkan Aktifitas Belajar, Hasil Belajar dan Respon Belajar siswa pada Mata Pelajaran Ekonomi. Jurnal Pendidikan Ekonomi Vol. 2. No. 1. Hal 38-52. http://lib.unnes.ac.id/7739/1/10301.pdf

Rifai, Achmad dan Chatarina Tri Anni. 2009. Psikologi Pendidikan. Semarang: UNNES PRESS

Slameto. 2003. Belajar dan Faktor-Faktor yang Mempengaruhi. Jakarta: Rineka Cipta 